\title{
Effect of Gamma Irradiation on the Shelf Life and Quality of Mutton
}

\author{
Md Azharul Islam, ${ }^{1, a}$, Md Anwar Hossain ${ }^{1, b}$, Md Sadakuzzaman ${ }^{1, c}$, Muckta Khan ${ }^{1, d}$, \\ Md Mukhlesur Rahman",e Md Abul Hashem, ${ }^{1, \text {, * }}$ \\ ${ }^{1}$ Department of Animal Science, Bangladesh Agricultural University, Mymensingh-2202, Bangladesh \\ *Corresponding author
}

\section{A R T I C L E I N F A B S T R A C T}

Research Article

Received : 30/11/2020 Accepted : 05/10/2021

The present study was undertaken to assay the effects of gamma irradiation on fresh mutton compared with non-irradiated mutton. For this purpose the meat samples were divided into four treatments. The experiment was conducted on fresh mutton treated with ${ }^{60} \mathrm{Co}$ gamma irradiation having dose of $0\left(\mathrm{~T}_{0}\right), 1.5\left(\mathrm{~T}_{1}\right), 2\left(\mathrm{~T}_{2}\right)$ and $4 \mathrm{kGy}\left(\mathrm{T}_{3}\right)$ and stored in 0,30 and 60 days at $-20^{\circ} \mathrm{C}$ to estimate the effect on proximate, sensory, physicochemical, biochemical and microbial changes in mutton. Proximate analysis (DM, CP, EE, and Ash), physicochemical and bio-chemical tests ( $\mathrm{pH}$ value, cooking loss, PV, TBARS and FFA), sensory tests (color, flavor, tenderness, juiciness, overall acceptability) and microbial test (TVC, TCC and TYMC) were done to evaluate the effect of irradiation on shelf life and quality of mutton during preservation. The mutton samples were stored up to 2 months and evaluated at 0,30 and $60^{\text {th }}$ day. Irradiation increased DM, EE and decreased ash of mutton. CP was decreased with treatment. The PV, TBARS, FFA values and Cooking loss were increased with treatment. But raw $\mathrm{pH}$ was decreased with irradiation. There were significant differences in color and flavor with treatment. There were no significant differences in tenderness, juiciness and overall acceptability with treatment. The TVC $(\log \mathrm{CFU} / \mathrm{g})$, TCC $(\log \mathrm{CFU} / \mathrm{g})$ and TYMC $(\log \mathrm{CFU} / \mathrm{g})$ were decreased with treatment. As a result, it can be concluded that irradiation increased shelf life of mutton to maintain nutritional quality of meat. Among the treatments, the highest irradiation dose $(4.0 \mathrm{KGy})$ found the best results in terms of overall acceptability, microorganism control and for shelf life extension of mutton.

Keywords:

Mutton

Peroxide value

Free fatty acid value

Microbiological values
(iD) $h t t p: / / o r c i d . o r g / 0000-0002-6177-0717$
(iD) $h t t p: / / o r c i d . o r g / 0000-0003-1973-3573$
(iD) https://orcid.org/0000-0002-9279-4869

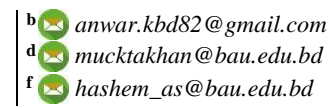

(iD http://orcid.org/0000-0003-3407-7703
(i) http://orcid.org/0000-0002-1629-8150
(i) https://orcid.org/0000-0001-5691-3544 a azharbau084@gmail.com
'@sdkahps@gmail.com
e@mmrahman.as@bau.edu.bd

This work is licensed under Creative Commons Attribution 4.0 International License

\section{Introduction}

Sheep is the $3^{\text {rd }}$ largest ruminant animal in Bangladesh and plays a significant role in meat production in Bangladesh. About $23 \%$ of ruminant animals were slaughtered every year and among them $7 \%$ of these animals were slaughtered in a single day at Eid ul Adha in Bangladesh (Akter et al., 2009). A surplus amount of meat produced during Eid ul Adha needs to be preserved safely for further consumption. Several methods were used to preserve meat such as drying (Akhter et al., 2009), freezing (Bithi et al., 2020; Modak et al., 2009; Rahman et al., 2014), curing (Inguglia et al., 2018), smoking (Bruneau et al., 2005), and irradiation (Haque et al., 2017; Islam et al., 2019; Rima et al., 2019). Irradiation is a physical means of sterilization or decontamination where products are exposed to gamma rays. Gamma-rays are electromagnetic waves emitted from radioactive isotopes such as cobalt-60 or cesium-137 that have strong penetration (Shin et al., 2014). Electron-beams are mechanically generated by electron accelerator and directly irradiate products, it has advantages of control convenience and favorable perception consumer acceptance, but weak penetration power compared to gamma-ray. A recent study has indicated that three radiation sources (gamma-ray, electron-beam and X-ray) led to different efficacies on microbial properties as well as color characteristics and lipid oxidation stability. Gamma-ray irradiation increases the redness of pork sausages; on the other hand it decreases by electron-beam irradiation at higher dose level. Electronbeam irradiation effectively reduced the total aerobic bacteria in beef patties whereas, gamma-ray considerably decreased microbes in pork sausages as irradiation level increased (Ham et al., 2017). Several methods which include cooking, freezing, fermenting, salting, drying and pickling (Choi et al., 2009; Kim et al., 2009) have been used to reduce the number of microorganisms and increase the shelf-life and safety of meat. However, one of the most 
promising approaches to improve microbial safety of meat would be the use of low or medium-dose (1-10 kGy) irradiation (WHO, 1999). Several researchers have stated that irradiation can control efficiently the growth of pathogenic and spoilage bacteria in meat (Zhu et al., 2005; Islam et al., 2019).

Irradiation extends shelf life, destroy pest, reduces infection from food borne pathogens or parasites and has been shown to be a healthy state (Thayer et al., 1995). Oxidation of lipid and lipid substances are the major causes of reducing the quality of meat during storage. Adoption of irradiation on meat induces the production of free radicals which react with oxygen, leading to the formation of carbonyls that helps to maintain the nutritional and sensorial characteristics of meat. Food irradiation technology has been practically used as an effective preservative method to not only reduce initial microbial contamination, but also delay microorganism growth during storage in meat products (Kim et al., 2012; Roberts, 2014). The U.S. Food Safety and Inspection Service approved irradiation of red meat in 1997 (FSIS, USDA, 2008). Irradiation doses required to kill pathogens can cause undesirable changes in meat color, flavor and odor (Nam et al., 2003). Irradiation is the most effective technology in eliminating these pathogens in meat products. Most of the irradiation studies so far are mainly focused on raw meat and meat products without additives and little information on the quality changes of ready to eat meat products by irradiation are available. Irradiating uncooked meat produced a characteristic blood-spattered and a pleasant aroma that remained after cooking (Hashim et al., 1995).

Lately Bangladesh is producing 72.60 Lakh MT where as demand of 72.14 Lakh MT (DLS, 2018) where mutton is contributing $12 \%$ of total meat production. It indicates that Bangladesh is self sufficient in meat production and the amount of surplus is 0.46 Lakh MT. As a result now we have opportunity to seek foreign markets to export our excess meats. It is essential to develop a way to increase the shelf life and quality of raw meat to overcome the international trade barrier. In this case, irradiation can be an effective way to increase the shelf life and safety of meats. At present in Bangladesh, no research has yet been carried out on irradiation of mutton. Therefore, the present study was undertaken to determine the effect of gamma irradiation on sensory, proximate component, biochemical and microbial parameters of mutton and also to find out the suitable level of irradiation dosage on mutton to increase the shelf life.

\section{Materials and Methods}

\section{Sample Collection, Processing and Irradiation}

Boneless mutton from freshly slaughtered three indigenous Bangladeshi sheep of same age, sex and body condition was collected from local market of Bangladesh Agricultural University, Mymensingh. Meat samples (500gm from each sheep) were collected from the same location (shoulder) of all three sheep. Then the samples were immediately transferred to the Laboratory of Animal Science. Fat, ligaments, bone and tendons were trimmed with sharp knives and cleaned with distilled water. After that, the meat samples were divided into four groups and labeled with specific radiation dose. Each group was exposed to the irradiation dose of $0\left(\mathrm{~T}_{0}\right), 1.5\left(\mathrm{~T}_{1}\right), 2\left(\mathrm{~T}_{2}\right)$ and $4 \mathrm{kGy}\left(\mathrm{T}_{3}\right)$ at the Bangladesh Institute of Nuclear Agriculture (BINA) using Cobalt 60 GC-5000 (BRIT, India) machine for irradiation source and stored at $-20^{\circ} \mathrm{C}$ for pending analysis.

\section{Quality Analysis}

Different proximate, sensory and bio-chemical measurements were examined. Mutton samples were through panel test consisting of 6-8 members. Panelists were selected among department staff and students and trained according to the American Meat Science Association guidelines (AMSA, 1995). The sensory questionnaires measured on a 5-point balanced semantic scale (weak to strong) for the following attributes color, smell, tenderness, juiciness, and overall acceptability. The judges evaluated the samples based on AMSA guidelines. Evaluation was done in individual booth under controlled conditions of light, temperature and humidity. Before the evaluation process, all the panelists participated in an orientation session to familiarize with the meat judging (color, flavor, juiciness, tenderness, overall acceptability) of mutton using an intensity scale. Sensory qualities of the mutton samples were judged after thawing at before and after cook with a 5-point rating scale. Sensory scores were 5 for excellent, 4 for very good, 3 for good, 2 for fair and 1 for poor (Rahman et al., 2012). All samples were served in the Petri dishes. Sensory evaluation was done at 0 day and repeated at 30 and 60 days; up to the end of the refrigerated storage at $-20 \pm 1^{\circ} \mathrm{C}$.

Proximate nutrients analysis

Proximate composition such as dry matter (DM), ether extracts (EE), crude protein (CP) and ash were determined according to the methods of AOAC (2005). All the parameters were done in triplicate and the mean values were incorporated.

\section{Physicochemical and Biochemical analysis}

Two physicochemical analyses such as $\mathrm{pH}$ value of raw meat and cooking loss; three biochemical analysis such as Free Fatty Acid (FFA), Peroxide Value (POV), Thiobarbituric Acid values (TBARS) were measured.

\section{Raw pH Measurement}

The $\mathrm{pH}$ value of raw meat was measured using $\mathrm{pH}$ meter from raw meat homogenate. The homogenate was prepared by blending $5 \mathrm{~g}$ of meat with $10 \mathrm{ml}$ distilled water.

\section{Cooking Loss}

To determine cooking loss, five (5) g sample was wieghed and wrapped in a foil paper and it was heated in a water bath for 30 minutes at $75^{\circ} \mathrm{C}$. The temperature of water bath was measured by a digital food grade thermometer (HT-2). It needed approximately 30 minutes to attain a temperature up to $75^{\circ} \mathrm{C}$. After that the sample surfaces were dried and weighed to measure cooking loss.

The weight of the samples was weighed before and after the heat treatment. Cooking loss is expressed as the ratio of weight loss over the initial weight, using the follow formula:

$$
\text { Cooking loss } \%=\frac{w 1-w 2}{w 2} \times 100
$$

Where, $\mathrm{w}_{1}=$ meat weight before cooking $(\mathrm{g})$ and $\mathrm{w}_{2}=$ meat weight after cooking $(\mathrm{g})$. 
Free Fatty Acid (\%) Analysis

The ree fatty acid value of fresh mutton was determined according to the method adopted by Rukunudin et al. (1998) and expressed as percentage. The determination of FFA using the following equation:

FFA $(\%)=$ Titration volume $\times$ normality of $\mathrm{KOH} \times$ $28.2 / \mathrm{g}$ of sample

\section{Peroxide Value (POV) Analysis (meq/kg)}

The Peroxide value (POV) was estimated according to the method adopted by Sallam et al. (2004). The determination of peroxide value was determined using following equation:

$$
\mathrm{POV}(\mathrm{meq} / \mathrm{kg})=\frac{s \times N}{W} \times 100
$$

Where $\mathrm{S}$ is the volume of titration $(\mathrm{ml}), \mathrm{N}$ the normality of sodium thiosulfate solution $(\mathrm{n}=0.01)$ and $\mathrm{W}$ the sample weight $(\mathrm{g})$.

\section{Thiobarbituric Acid Values (TBARS)}

Thiobarbituric Acid Values (TBARS) were determined to assess the lipid oxidation status of a supplied sample. It was done in triplicate using the 2-thiobarbituric acid method adopted by Schmedes and Homer (1989). The TBARS value was expressed as milligram malonaldehyde per kilogram of mutton sample.

\section{Microbial assessment}

Microbial assessments such as total viable count, coliform and yeast-mould count were determined. Approximately $10 \mathrm{~g}$ of mutton sample was aseptically exercised from stored stock sample. Each stored meat samples was aseptically exercised. Each stored meat sample was thoroughly and uniformly blended in a mechanical blender using sterile diluents $(0.1 \%$ peptone water) as per recommendation of International Organization for Standardization. About $10 \mathrm{~g}$ of ground mutton sample was taken aseptically and transferred to a sterile container that contains $90 \mathrm{ml}$ of $0.1 \%$ peptone water. Then a homogenized suspension was prepared with a sterile blender and thus 1:10 dilution of sample was produced. A whirly mixture machine of different serial dilutions ranging from $10^{-2}$ to $10^{-6}$ were counted through a colony counter. Average number of colonies in a particular dilution was multiplied by the dilution factor to obtain total coliform count. Total coliform count was calculated according to ISO (1995). The results of total coliform count were expressed as the number of an organism of colony forming units per gram (CFU/g) of mutton sample.

\section{Statistical Analysis}

The used model for the planned experiment was factorial experiment with two factors A (Treatments) and $\mathrm{B}$ (Days of Intervals) is:

$Y_{i j k}=\mu+A_{i}+B_{j}+(A B)_{i j}+e_{i j k i}=1, \ldots, a ; j=1, \ldots, b ; k=1, \ldots, n$

Where:

$\mathrm{Y}_{\mathrm{ijk}}=$ observation $\mathrm{k}$ in level $\mathrm{i}$ of factor $\mathrm{A}$ and level $\mathrm{j}$ of factor $B$

$\mu \quad=$ the overall mean

$\mathrm{A}_{\mathrm{i}} \quad=$ the effect of level $\mathrm{i}$ of factor $\mathrm{A}$

$B_{j} \quad=$ the effect of level $\mathrm{j}$ of factor $B$
Data were analyzed using SAS Statistical Discovery software, NC, USA. Duncan's Multiple Range Test (DMRT) was used to assess the differences among treatments.

\section{Results and Discussion}

\section{Sensory Evaluation}

Color

The values of color of the sample are presented in the Table 1. Gamma Irradiation increased the color of mutton significantly $(\mathrm{P}<0.05)$. The range of overall observed color score at different doses of irradiation was 3.33 to 4.33 . The color value was decreased significantly with storage time and the range was 4.66 to $3.25(\mathrm{P}<0.05)$. Kim et al. (2012) stated that the redness of meat increased with the formation of carbon onoxide- myoglobin ( $\mathrm{CO}-\mathrm{Mb})$ complexes. The $\mathrm{CO}-\mathrm{Mb}$ complex is not easily oxidized to brown metmyoglobin compared with oxymyoglobin due to the strong binding of $\mathrm{CO}$ to the iron-porphyrin in myoglobin molecule. They also stated that gamma-ray increased the redness of pork sausages at higher at higher dose level (Ham et al., 2017). Similar results also found by Miller et al. (1995) that irradiation increased the intensity of the color of meat. Nam et al. (2003) observed that different mechanisms and pigments were responsible for irradiationinduced color changes in meat and meat products.

\section{Flavor}

The score of mean flavors of irradiated and nonirradiated with treatments and days interval are shown in Table 1. The flavor was significantly decreased with treatment (range of flavor score was 4.33 to 3.33) $(\mathrm{P}<0.05)$. The flavor was significantly $(\mathrm{P}<0.05)$ decreased with days interval and the range of flavor among different days interval was 4.33 to 3.12. Similar results were also found by Modi et al. (2008) where they revealed changes in a goat meat flavor due to gamma irradiation. Irradiation is also known to produce off-odors and off-flavors in food products including beef by the formation of radiolysis products that are dependent on radiation dose, dose rate, packaging conditions and temperature (Jung, 2007).

\section{Tenderness}

Tenderness in both irradiated and non-irradiated mutton with different days of intervals is shown in Table 1. The range of values of tenderness score at different treatments was 3.66 to 4.11 and there was no significant effect of irradiation on tenderness of mutton ( $\mathrm{P}>0.05)$. Tenderness was significantly decreased with storage time (range was 4.58 to 3.25$)(\mathrm{P}<0.05)$. Similar results were also found in beef in the different study of the same research group Haque et al. (2017). Sweetie et al. (1015) reported that collagen is an abundant tissue protein that plays a significant role in the tenderness and texture of meat. Cheung et al. (1990) found a significant damage of collagen fibers at a higher dose of gamma irradiation. Morever, molecular weight was also significantly reduced due to cleavese of peptide bonds through radiation which could cause considerable changes in the long-term characteristics of meat. The cross linkage of collagen, actin and reticulin in the endomycium, perimycium and epimycium are responsible for the toughness of meat. Therefore, gamma irradiation might be a suitable tool to prepare tenderer meat through break down of collagen cross linkage. 
Table 1. Effect of irradiation on sensory attributes of mutton (mean $\pm \mathrm{SE}$ )

\begin{tabular}{|c|c|c|c|c|c|c|c|c|c|}
\hline \multirow{2}{*}{ Parameter } & \multirow{2}{*}{ DI } & \multicolumn{4}{|c|}{ Treatment } & \multirow{2}{*}{ Mean \pm SE } & \multicolumn{3}{|c|}{ Level of significance } \\
\hline & & $\mathrm{T}_{1}$ & $\mathrm{~T}_{2}$ & $\mathrm{~T}_{3}$ & $\mathrm{~T}_{4}$ & & $\mathrm{~T}$ & DI & $\mathrm{T} \times \mathrm{DI}$ \\
\hline \multirow{4}{*}{ Colour } & 0 & $4.33 \pm 0.33$ & $4.66 \pm 0.33$ & $4.66 \pm 0.33$ & $5.00 \pm 00$ & $4.66^{\mathrm{a}} \pm 0.24$ & \multirow{4}{*}{0.0020} & \multirow{4}{*}{$<.0001$} & \multirow{4}{*}{0.7000} \\
\hline & 30 & $3.33 \pm 0.33$ & $4.33 \pm 0.33$ & $4.66 \pm 0.33$ & $4.33 \pm 0.33$ & $4.16^{\mathrm{b}} \pm 0.33$ & & & \\
\hline & 60 & $2.33 \pm 0.33$ & $3.33 \pm 0.33$ & $3.66 \pm 0.33$ & $3.66 \pm 0.33$ & $3.25^{\mathrm{c}} \pm 0.33$ & & & \\
\hline & Mean & $3.33^{\mathrm{b}} \pm 0.33$ & $4.11^{\mathrm{a}} \pm 0.33$ & $4.33^{\mathrm{a}} \pm 0.33$ & $4.33^{\mathrm{a}} \pm 0.22$ & & & & \\
\hline \multirow{4}{*}{ Flavour } & 0 & $4.66 \pm 0.33$ & $4.33 \pm 0.33$ & $4.33 \pm 0.33$ & $4.00 \pm 0.57$ & $4.33^{\mathrm{a}} \pm 0.39$ & \multirow{4}{*}{0.0116} & \multirow{4}{*}{0.0002} & \multirow{4}{*}{0.6537} \\
\hline & 30 & $4.33 \pm 0.33$ & $4.00 \pm 0.00$ & $3.33 \pm 0.33$ & $3.66 \pm 0.33$ & $3.83^{\mathrm{a}} \pm 0.24$ & & & \\
\hline & 60 & $4.00 \pm 0.00$ & $3.16 \pm 0.16$ & $3.00 \pm 0.57$ & $2.33 \pm 0.33$ & $3.12^{\mathrm{b}} \pm 0.26$ & & & \\
\hline & Mean & $4.33^{\mathrm{a}} \pm 0.22$ & $3.83^{\mathrm{ab}} \pm 0.16$ & $3.55^{\mathrm{b}} \pm 0.41$ & $3.33^{b} \pm 0.41$ & & & & \\
\hline \multirow{4}{*}{ Tenderness } & 0 & $4.33 \pm 0.33$ & $5.00 \pm 00$ & $4.66 \pm 0.33$ & $4.33 \pm 0.66$ & $4.58^{\mathrm{a}} \pm 0.33$ & \multirow{4}{*}{0.6810} & \multirow{4}{*}{0.0018} & \multirow{4}{*}{0.8281} \\
\hline & 30 & $3.66 \pm 0.33$ & $4.00 \pm 00$ & $4.33 \pm 0.33$ & $3.66 \pm 0.66$ & $3.91^{\mathrm{ab}} \pm 0.33$ & & & \\
\hline & 60 & $3.00 \pm 0.57$ & $3.33 \pm 0.33$ & $3.00 \pm 0.57$ & $3.66 \pm 0.66$ & $3.25^{b} \pm 0.53$ & & & \\
\hline & Mean & $3.66^{\mathrm{a}} \pm 0.41$ & $4.11^{\mathrm{a}} \pm 0.11$ & $4.00^{\mathrm{a}} \pm 0.41$ & $3.88^{\mathrm{a}} \pm 0.66$ & & & & \\
\hline \multirow{4}{*}{ Juiciness } & 0 & $4.00 \pm 00$ & $4.66 \pm 0.33$ & $4.66 \pm 0.33$ & $5.00 \pm 00$ & $4.58^{\mathrm{a}} \pm 0.16$ & \multirow{4}{*}{0.2007} & \multirow{4}{*}{$<.0001$} & \multirow{4}{*}{0.9004} \\
\hline & 30 & $3.66 \pm 0.66$ & $3.66 \pm 0.33$ & $4.33 \pm 0.33$ & $4.33 \pm 0.33$ & $4.00^{\mathrm{b}} \pm 0.41$ & & & \\
\hline & 60 & $3.00 \pm 0.57$ & $3.00 \pm 0.57$ & $3.00 \pm 00$ & $3.33 \pm 0.33$ & $3.08^{c} \pm 0.36$ & & & \\
\hline & Mean & $3.55^{\mathrm{a}} \pm 0.41$ & $3.77^{\mathrm{a}} \pm 0.41$ & $4.00^{\mathrm{a}} \pm 0.22$ & $4.22^{\mathrm{a}} \pm 0.22$ & & & & \\
\hline \multirow{4}{*}{$\begin{array}{l}\text { Overall } \\
\text { Acceptability }\end{array}$} & 0 & $4.33 \pm 0.33$ & $4.66 \pm 0.33$ & $4.66 \pm 0.33$ & $4.66 \pm 0.33$ & $4.58^{\mathrm{a}} \pm 0.33$ & \multirow{4}{*}{0.6843} & \multirow{4}{*}{0.0027} & \multirow{4}{*}{0.8960} \\
\hline & 30 & $3.66 \pm 0.33$ & $3.33 \pm 0.33$ & $4.00 \pm 00$ & $4.16 \pm 0.44$ & $3.79^{\mathrm{b}} \pm 0.27$ & & & \\
\hline & 60 & $3.33 \pm 0.88$ & $3.66 \pm 0.33$ & $3.33 \pm 0.33$ & $3.66 \pm 0.33$ & $3.50^{\mathrm{b}} \pm 0.46$ & & & \\
\hline & Mean & $3.77^{\mathrm{a}} \pm 0.51$ & $3.88^{\mathrm{a}} \pm 0.33$ & $4.00^{\mathrm{a}} \pm 0.22$ & $4.16^{\mathrm{a}} \pm 0.36$ & & & & \\
\hline
\end{tabular}

Means in each row having different superscripts vary significantly at values $\mathrm{P}<0.05$. Again, mean values having same superscript in each row did not differ significantly at $\mathrm{P}>0.05$. $\mathrm{T}_{1}=$ Controlled group, $\mathrm{T}_{2}=1.5 \mathrm{kGy}$ irradiated group, $\mathrm{T}_{3}=2 \mathrm{kGy}$ irradiated group $\mathrm{T}_{4}=4 \mathrm{kGy}$ irradiated group, $\mathrm{DI}=\mathrm{Days}$ of Interval, $\mathrm{T}=$ Treatment, $\mathrm{T} \times \mathrm{DI}=$ Interaction of Treatment and Days of Interval.

Table 2. Effect of irradiation of proximate component of mutton (mean $\pm \mathrm{SE}$ )

\begin{tabular}{|c|c|c|c|c|c|c|c|c|c|}
\hline \multirow{2}{*}{ Parameter } & \multirow{2}{*}{ DI } & \multicolumn{4}{|c|}{ Treatment } & \multirow{2}{*}{ Mean $\pm \mathrm{SE}$} & \multicolumn{3}{|c|}{ Level of significance } \\
\hline & & $\mathrm{T}_{0}$ & $\mathrm{~T}_{1}$ & $\mathrm{~T}_{2}$ & $\mathrm{~T}_{3}$ & & $\mathrm{~T}$ & DI & $\mathrm{T} \times \mathrm{DI}$ \\
\hline \multirow{4}{*}{ DM (\%) } & 0 & $20.92 \pm 0.008$ & $21.83 \pm 0.009$ & $22.66 \pm 0.009$ & $23.53 \pm 0.011$ & $22.23^{\mathrm{c}} \pm 0.010$ & \multirow{4}{*}{$<.0001$} & \multirow{4}{*}{$<.0001$} & \multirow{4}{*}{$<.0001$} \\
\hline & 30 & $21.91 \pm 0.020$ & $22.81 \pm 0.003$ & $23.76 \pm 0.009$ & $24.56 \pm 0.011$ & $23.26^{\mathrm{b}} \pm 0.010$ & & & \\
\hline & 60 & $22.28 \pm 0.005$ & $23.25 \pm 0.005$ & $24.08 \pm 0.006$ & $24.91 \pm 0.015$ & $23.63^{\mathrm{a}} \pm 0.008$ & & & \\
\hline & Mean & $21.70^{\mathrm{d}} \pm 0.011$ & $22.63^{c} \pm 0.006$ & $23.50^{\mathrm{b}} \pm 0.008$ & $24.33^{\mathrm{a}} \pm 0.012$ & & & & \\
\hline \multirow{4}{*}{$\mathrm{CP}(\%)$} & 0 & $21.70 \pm .005$ & $21.73 \pm 0.005$ & $21.69 \pm 0.011$ & $21.61 \pm 0.006$ & 006 & \multirow{4}{*}{0.0057} & \multirow{4}{*}{$<.0001$} & \multirow{4}{*}{$<.0001$} \\
\hline & 30 & $19.64 \pm 0.012$ & $19.67 \pm 0.017$ & $19.60 \pm 0.012$ & $19.62 \pm 0.015$ & $19.72^{\mathrm{b}} \pm 0.014$ & & & \\
\hline & 60 & $17.43 \pm 0.011$ & $17.46 \pm 0.005$ & $17.48 \pm 0.009$ & $17.48 \pm 0.012$ & $17.46^{c} \pm 0.009$ & & & \\
\hline & Mean & $19.59^{\mathrm{ab}_{ \pm}} 0.009$ & $19.61^{\mathrm{a}} \pm 0.009$ & $19.58^{\mathrm{b}} \pm 0.010$ & $19.57^{b} \pm 0.011$ & & & & \\
\hline \multirow{4}{*}{$\mathrm{EE}(\%)$} & 0 & $12.50 \pm 0.020$ & $13.13 \pm 0.011$ & $13.64 \pm 0.017$ & $14.22 \pm 0.032$ & $13.37^{\mathrm{c}} \pm 0.02$ & \multirow{4}{*}{$<.0001$} & \multirow{4}{*}{$<.0001$} & \multirow{4}{*}{$<.0001$} \\
\hline & 30 & $12.94 \pm 0.017$ & $13.83 \pm 0.008$ & $14.74 \pm 0.020$ & $15.60 \pm 0.026$ & $14.28^{\mathrm{b}} \pm 0.017$ & & & \\
\hline & 60 & $14.26 \pm 0.031$ & $15.10 \pm 0.020$ & $15.97 \pm 0.008$ & $16.85 \pm 0.024$ & $15.54^{\mathrm{a}} \pm 0.020$ & & & \\
\hline & Mean & $13.23^{\mathrm{d}} \pm 0.022$ & $14.02^{\mathrm{c}} \pm 0.013$ & $14.78^{\mathrm{b}} \pm 0.015$ & $15.56^{\mathrm{a}} \pm 0.027$ & & & & \\
\hline \multirow{4}{*}{$\mathrm{ASH}(\%)$} & 0 & $2.02 \pm 0.093$ & $1.94 \pm 0.075$ & $1.82 \pm 0.053$ & $1.70 \pm 0.049$ & & \multirow{4}{*}{$<.0001$} & \multirow{4}{*}{0.0453} & \multirow{4}{*}{0.9967} \\
\hline & 30 & $2.00 \pm 0.093$ & $1.88 \pm 0.091$ & $1.75 \pm 0.085$ & $1.62 \pm 0.070$ & $1.81^{\mathrm{ab}} \pm 0.084$ & & & \\
\hline & 60 & $1.95 \pm 0.028$ & $1.81 \pm 0.030$ & $1.67 \pm 0.037$ & $1.56 \pm 0.033$ & $1.75^{\mathrm{b}} \pm 0.032$ & & & \\
\hline & Mean & $1.99^{\mathrm{a}} \pm 0.071$ & $1.88^{\mathrm{b}} \pm 0.065$ & $1.75^{\mathrm{c}} \pm 0.058$ & $1.63^{\mathrm{d}} \pm 0.050$ & & & & \\
\hline
\end{tabular}

Means in each row having different superscripts vary significantly at values $\mathrm{P}<0.05$. Again, mean values having same superscript in each row did not differ significantly at $\mathrm{P}>0.05$. $\mathrm{T}_{0}=$ Control group, $\mathrm{T}_{1}=1.5 \mathrm{kGy}$ irradiated group, $\mathrm{T}_{2}=2 \mathrm{kGy}$ irradiated group $\mathrm{T}_{3}=4 \mathrm{kGy}$ irradiated group, DI=Days of Interval, $\mathrm{T}=$ Treatment, $\mathrm{T} \times \mathrm{DI}=$ Interaction of Treatment and Days of Interval.

\section{Juiciness}

Mean scores in both irradiated and non-irradiated mutton have shown in Table 1 . The values of juiciness at different treatments were ranges 3.55 to 4.22 and there was no significant effect of irradiation on the juiciness values of mutton $(\mathrm{P}>0.05)$. Juiciness was significantly decreased and the range of juiciness score was 4.58 to 3.08 with storage time $(\mathrm{P}<0.05)$. Similarly, Badr $(2004)$ found that irradiation in rabbit meat had no significant effect on the juiciness. Miyagusku et al. (2003) examined chicken breast meat and stated that $3.0 \mathrm{kGy}$ level of irradiation dosage increases the shelf life from 5 to 22 days without modifying the sensory parameters.

\section{Overall Acceptability}

The overall acceptability values at different treatments were ranges 3.77 to 4.16 . Irradiation doses slightly increased overall acceptability of meat but it was not significant $(\mathrm{P}>0.05)$. As well, Johnson et al. (2004) found significant difference between the irradiated and nonirradiated meat. The range of overall acceptability score was 4.58 to 3.50 with different days of interval. The overall acceptability significantly decreased with storage time $(\mathrm{P}<0.05)$. Johnson et al. (2004) also found that overall acceptance, acceptance of flavor, juiciness, tenderness and mouth feeling of the non-irradiated chicken and its products were significantly lower than irradiated samples 
at day 18 and day 32 after irradiation, respectively $(\mathrm{P}<0.05)$. Haque et al. (2017) found the similar results of overall acceptability in beef.

\section{Proximate Analysis}

Effects of gamma irradiation on the proximate composition of mutton are presented in Table 2. Apparently, irradiation treatments brought only minor changes in the DM, CP, EE and ash contents of meats.

\section{Dry Matter (DM)}

DM content of mutton was increased significantly with irradiation $(\mathrm{P}<0.05)$. The range of DM content at different treatments was $21.70 \%$ to $24.33 \%$. DM content also increased and the range was $22.23 \%$ to $23.63 \%$ with storage time $(\mathrm{P}<0.05)$. Extra cellular fluid of meat might be shrinked during erradiation process, resulting in less moisture content in the muscle. As the irradiation breaks the collagen and other fibers might helps to reduce or evaporate water from muscle after irradiaton (Cheung et al., 1990). Al-Bachir and Zeinou (2009) and Modi et al. (2008) were also found the similar patterns in which moisture percentage was decreased with increasing irradiation dosage and storage time. A similar pattern was also observed by Konieczny et al. (2007) where they reported that DM content increased with the advancement of storage time.

\section{Crude Protein (CP)}

The range of $\mathrm{CP} \%$ at different treatment level was 19.57 to $19.61 \%$. Results showed that the highest level $(\mathrm{P}<0.05)$ of $\mathrm{CP} \%$ was found in $1.5 \mathrm{kGy}$ irradiated group than that of other treatment group. Unlikely, Modi et al. (2008), Al-Bachir and Zeinou (2009) and Haque et al. (2017) found that CP content of meat did not significantly change due to irradiation. The $\mathrm{CP}$ content significantly decreased with storage time which ranges from 21.68 to $17.46 \%(\mathrm{p}<0.05)$ and these results are in agreement with Al-Bachir and Zeinou (2009) where CP content decreased with increasing storage time in meat and meat products.

\section{Ether Extract (EE)}

Irradiated samples showed significantly higher amounts of EE compared with controlled group $(\mathrm{P}<0.05)$. The effect of the gamma irradiation on the fatty acid composition can be ascribed to the production of free radicals during the irradiation of mutton. Water losses occurred during irradiation that resulting a higher DM content in irradiated mutton than in non-irradiated might be the cause of higher lipid content in most cases. This result may be explained by the inverse relationship between fat and moisture contents or a dose-dependent effect of irradiation on the fatty acid profile (Stefanova et al., 2011). The higher amount fat content might be due to the degradation of large lipid molecules which ultimately added to the fat content of the sample. This trend was similar to that of (Al-Bachir and Zeinou, 2009; Yilmaz and Gecgel, 2007; Fernandez-Lopez et al., 2003). The EE content (13.37 to $15.54 \%$ ) also significantly increased with storage time $(\mathrm{P}<0.05)$. The results in this study were very close with the findings of Al-Bachir and Zeinou (2009) and Bakalivanova et al. (2009).

$$
\text { Ash }
$$

The ash content of both irradiated and non-irradiated meat was shown in Table 2. Ash content was significantly decreased with the increasing of irradiation dosage
$(\mathrm{P}<0.05)$ but insignificant in days of intervals as well as interaction of treatment and days of intervals. Decreasing of ash content after irradiation might be due to the physical disruption of muscle fibers and also increasing of oxidation and peroxide values during irradiation process. Al-Bachir and Zeinou (2009) stated that ash content of meat slightly increased with different irradiation dosage as well as days of intervals but these were not significant. Gecgel (2013) reported similar findings for meatballs, but their samples were irradiated at doses up to $7.0 \mathrm{kGy}$. Arannilewa et al. (2005) observed that ash content of the meat is decreased with frozen storage. A similar result was also found by Haque et al. (2017) in beef.

\section{Physicochemical and Bio-chemical Properties}

The physicochemical and Bio-chemical properties such as raw $\mathrm{pH}$, cooking loss, PV, TBARS, FFA were determined and the results are presented in Table 3.

\section{Raw $p H$}

The range of raw $\mathrm{pH}$ was $5.86 \%$ to $5.74 \%$ with irradiation dose. The $\mathrm{pH}$ value was decreased significantly with increasing doses of irradiation $(\mathrm{P}<0.05)$. This is because an increase in fat values in irradiated samples caused decrease raw $\mathrm{pH}$ of meat (Morales et al. 2009). Raw $\mathrm{pH}$ also significantly decreased with storage time due to increased free fatty acids because of rancidity $(\mathrm{P}<0.05)$. Similar result also found in irradiated broiler meat where the $\mathrm{pH}$ was slightly decreased with the increasing of irradiation as well as with the advancement of storage time in refrigerator (Morales et al. 2009). Similarly, Aftab et al. (2015) also found that raw $\mathrm{pH}$ was decreased with higher irradiation as well as storage.

\section{Cooking Loss}

The range of cooking loss at different treatments was $38.58 \%$ to $40.76 \%$. The results showed that cooking loss was significantly increased with irradiation doses as well as days of interval $(\mathrm{P}<0.05)$. Irradiation as well as storage time decreased muscle fiber that was the cause of increased cooking losses. Yoon (2003) reported that irradiated chicken breast showed a higher cooking loss than nonirradiated meat also supported the present study.

Peroxide Value (PV-meq/kg)

The range of overall observed $\mathrm{PV}$ at different treatment levels was 0.44 to 0.95 . PV values were increased significantly with increasing irradiation doses $(\mathrm{P}<0.05)$. The PV values also increased significantly with storage time and the overall observed values were 0.54 to 0.65 $(\mathrm{p}<0.05)$. Similarly, the PV was increased in beef with the increased irradiation dosage (Haque et al., 2017; Quattara et al., 2002).

\section{Thiobarbituric Acid Value (TBARS)}

The range of TBARS value of different treatment was 0.42 to 0.61 . The TBARS values were increased significantly with increased treatment doses and storage time $(\mathrm{P}<0.05)$. The results of the present study are very much similar with the few other researches (Al-Bachir and Zeinou, 2009; Bakalivanova et al., 2009). They reported an increase in oxidation activity and lipid peroxidation as a result of both irradiation treatment and storage time on meat and meat products. Kanatt et al. (2006) showed that TBA value increased during irradiation and storage in lamb meat. 
Table 3. Effect of irradiation on physicochemical and bio-chemical properties of mutton ( $m e a n \pm \mathrm{SE})$

\begin{tabular}{|c|c|c|c|c|c|c|c|c|c|}
\hline \multirow{2}{*}{ Parameter } & \multirow{2}{*}{ DI } & \multicolumn{4}{|c|}{ Treatment } & \multirow{2}{*}{ Mean \pm SE } & \multicolumn{3}{|c|}{ Level of significance } \\
\hline & & $\mathrm{T}_{0}$ & $\mathrm{~T}_{1}$ & $\mathrm{~T}_{2}$ & $\mathrm{~T}_{3}$ & & $\mathrm{~T}$ & DI & $\mathrm{T} \times \mathrm{DI}$ \\
\hline \multirow{4}{*}{ Raw pH } & 0 & $5.91 \pm 0.005$ & $5.87 \pm 0.005$ & $5.82 \pm 0.014$ & $5.78 \pm 0.017$ & $5.84^{\mathrm{a}} \pm 0.010$ & \multirow{4}{*}{$<.0001$} & \multirow{4}{*}{$<.0001$} & \multirow{4}{*}{0.9635} \\
\hline & 30 & $5.85 \pm 0.006$ & $5.81 \pm 0.014$ & $5.77 \pm 0.017$ & $5.74 \pm 0.011$ & $5.79^{b} \pm 0.012$ & & & \\
\hline & 60 & $5.82 \pm 0.005$ & $5.80 \pm 0.005$ & $5.74 \pm 0.011$ & $5.71 \pm 0.020$ & $5.76^{\mathrm{c}} \pm 0.010$ & & & \\
\hline & Mean & $5.86^{\mathrm{a}} \pm 0.005$ & $5.82^{\mathrm{b}} \pm 0.008$ & $5.77^{c} \pm 0.014$ & $5.74^{\mathrm{d}} \pm 0.016$ & & & & \\
\hline \multirow{4}{*}{$\begin{array}{l}\text { Cooking } \\
\text { Loss }\end{array}$} & 0 & $34.66 \pm 0.018$ & $35.45 \pm 0.020$ & $36.16 \pm 0.008$ & $37.03 \pm 0.011$ & \pm 0.014 & \multirow{4}{*}{$<.0001$} & \multirow{4}{*}{$<.0001$} & \multirow{4}{*}{0.2012} \\
\hline & 30 & $38.94 \pm 0.020$ & $39.73 \pm 0.008$ & $40.36 \pm 0.008$ & $41.12 \pm 0.012$ & $40.04^{\mathrm{b}} \pm 0.012$ & & & \\
\hline & 60 & $42.15 \pm 0.017$ & $42.86 \pm 0.008$ & $43.47 \pm 0.008$ & $44.15 \pm 0.023$ & $43.16^{\mathrm{a}} \pm 0.014$ & & & \\
\hline & Mean & $38.58^{\mathrm{d}} \pm 0.018$ & $39.35^{\mathrm{c}} \pm 0.012$ & $40.00^{\mathrm{b}} \pm 0.008$ & $40.76^{\mathrm{a}} \pm 0.015$ & & & & \\
\hline \multirow{4}{*}{ PV } & 0 & $0.35 \pm 0.039$ & $0.43 \pm 0.008$ & $0.52 \pm 0.015$ & $0.88 \pm 0.012$ & \pm 0.018 & \multirow{4}{*}{$<.0001$} & \multirow{4}{*}{$<.0001$} & \multirow{4}{*}{0.0935} \\
\hline & 30 & $0.48 \pm 0.023$ & $0.53 \pm 0.017$ & $0.57 \pm 0.020$ & $0.95 \pm 0.017$ & $0.63^{\mathrm{a}} \pm 0.019$ & & & \\
\hline & 60 & $0.48 \pm 0.012$ & $0.55 \pm 0.011$ & $0.57 \pm 0.011$ & $1.03 \pm 0.011$ & $0.65^{\mathrm{a}} \pm 0.011$ & & & \\
\hline & Mean & $0.44^{\mathrm{d}} \pm 0.024$ & $0.50^{c} \pm 0.012$ & $0.55^{\mathrm{b}} \pm 0.015$ & $0.95^{\mathrm{a}} \pm 0.013$ & & & & \\
\hline \multirow{4}{*}{ TBARS } & 0 & $0.14 \pm 0.011$ & $0.19 \pm 0.011$ & $0.26 \pm 0.011$ & $0.35 \pm 0.014$ & \pm 0.011 & \multirow{4}{*}{$<.0001$} & \multirow{4}{*}{$<.0001$} & \multirow{4}{*}{0.4708} \\
\hline & 30 & $0.45 \pm 0.014$ & $0.51 \pm 0.014$ & $0.56 \pm 0.014$ & $0.65 \pm 0.014$ & $0.54^{\mathrm{b}} \pm 0.014$ & & & \\
\hline & 60 & $0.68 \pm 0.017$ & $0.71 \pm 0.017$ & $0.75 \pm 0.014$ & $0.83 \pm 0.014$ & $0.74^{\mathrm{a}} \pm 0.015$ & & & \\
\hline & Mean & $0.42^{\mathrm{d}} \pm 0.014$ & $0.47^{c} \pm 0.014$ & $0.52^{\mathrm{b}} \pm 0.013$ & $0.61^{\mathrm{a}} \pm 0.014$ & & & & \\
\hline \multirow{4}{*}{ FFA } & 0 & $0.61 \pm 0.017$ & $0.78 \pm 0.023$ & $0.87 \pm 0.008$ & $0.91 \pm 0.020$ & $0.79^{c} \pm 0.017$ & \multirow{4}{*}{$<.0001$} & \multirow{4}{*}{$<.0001$} & \multirow{4}{*}{$<.0001$} \\
\hline & 30 & $0.71 \pm 0.020$ & $0.85 \pm 0.011$ & $0.97 \pm 0.032$ & $1.08 \pm 0.017$ & $0.90^{\mathrm{b}} \pm 0.02$ & & & \\
\hline & 60 & $0.89 \pm 0.017$ & $1.06 \pm 0.029$ & $1.12 \pm 0.024$ & $1.25 \pm 0.020$ & $1.08^{a} \pm 0.022$ & & & \\
\hline & Mean & $0.74^{\mathrm{d}} \pm .018$ & $0.90^{\mathrm{c}} \pm .021$ & $0.99^{b} \pm 0.015$ & $1.08^{\mathrm{a}} \pm 0.019$ & & & & \\
\hline
\end{tabular}

Means in each row having different superscripts vary significantly at values $\mathrm{P}<0.05$. Again, mean values having same superscript in each row did not differ significantly at $\mathrm{P}>0.05$. $\mathrm{T}_{1}=$ Controlled group, $\mathrm{T}_{2}=1.5 \mathrm{kGy}$ irradiated group, $\mathrm{T}_{3}=2 \mathrm{kGy}$ irradiated group $\mathrm{T}_{4}=4 \mathrm{kGy}$ irradiated group, DI=Days of Interval, $\mathrm{T}=$ Treatment, $\mathrm{T} \times \mathrm{DI}=$ Interaction of Treatment and Days of Interval.

Table 4. Effect of different doses of irradiation on microbial quality (mean $\pm \mathrm{SE}$ ) of mutton

\begin{tabular}{|c|c|c|c|c|c|c|c|c|c|}
\hline \multirow{2}{*}{ Parameter } & \multirow{2}{*}{ DI } & \multicolumn{4}{|c|}{ Treatment } & \multirow{2}{*}{ Mean \pm SE } & \multicolumn{3}{|c|}{ Level of significance } \\
\hline & & $\mathrm{T}_{1}$ & $\mathrm{~T}_{2}$ & $\mathrm{~T}_{3}$ & $\mathrm{~T}_{4}$ & & $\mathrm{~T}$ & DI & $\mathrm{T} \times \mathrm{DI}$ \\
\hline \multirow{4}{*}{$\begin{array}{l}\text { TVC } \\
(\log C F U / g)\end{array}$} & 0 & $5.61 \pm 0.032$ & $5.06 \pm 0.050$ & $4.55 \pm 0.063$ & $3.65 \pm 0.068$ & $4.72^{\mathrm{c}} \pm 0.053$ & \multirow{4}{*}{$<.0001$} & \multirow{4}{*}{$<.0001$} & \multirow{4}{*}{0.1133} \\
\hline & 30 & $5.89 \pm 0.027$ & $5.13 \pm 0.043$ & $4.67 \pm 0.139$ & $3.76 \pm 0.150$ & $4.86^{\mathrm{b}} \pm 0.065$ & & & \\
\hline & 60 & $6.38 \pm 0.018$ & $5.30 \pm 0.125$ & $4.95 \pm 0.054$ & $4.06 \pm 0.050$ & $5.17^{\mathrm{a}} \pm 0.061$ & & & \\
\hline & Mean & $5.96^{\mathrm{a}} \pm 0.025$ & $5.16^{b} \pm 0.072$ & $4.73^{c} \pm 0.043$ & $3.82^{\mathrm{d}} \pm 0.089$ & & & & \\
\hline \multirow{4}{*}{$\begin{array}{l}\text { TCC } \\
(\log C F U / g)\end{array}$} & 0 & $2.03 \pm 0.038$ & $1.34 \pm 0.024$ & $1.14 \pm 0.050$ & $0.95 \pm 0.021$ & $1.36^{\mathrm{c}} \pm 0.033$ & \multirow{4}{*}{$<.0001$} & \multirow{4}{*}{$<.0001$} & \multirow{4}{*}{0.0031} \\
\hline & 30 & $2.57 \pm 0.056$ & $2.03 \pm 0.069$ & $1.75 \pm 0.026$ & $1.37 \pm 0.043$ & $1.93^{\mathrm{b}} \pm 0.048$ & & & \\
\hline & 60 & $2.92 \pm 0.015$ & $2.33 \pm 0.074$ & $1.83 \pm 0.029$ & $1.55 \pm 0.055$ & $2.16^{\mathrm{a}} \pm 0.043$ & & & \\
\hline & Mean & $2.51^{\mathrm{a}} \pm 0.036$ & $1.90^{b} \pm 0.055$ & $1.57^{c} \pm 0.035$ & $1.29^{\mathrm{d}} \pm 0.039$ & & & & \\
\hline \multirow{4}{*}{$\begin{array}{l}\text { TYMC } \\
(\log C F U / g)\end{array}$} & 0 & $3.13 \pm 0.009$ & $2.56 \pm 0.054$ & $2.18 \pm 0.043$ & $1.87 \pm 0.050$ & $2.43^{\mathrm{c}} \pm 0.039$ & \multirow{4}{*}{$<.0001$} & \multirow{4}{*}{$<.0001$} & \multirow{4}{*}{0.0002} \\
\hline & 30 & $3.61 \pm 0.180$ & $2.78 \pm 0.033$ & $2.42 \pm 0.046$ & $1.92 \pm 0.040$ & $2.68^{\mathrm{b}} \pm 0.074$ & & & \\
\hline & 60 & $4.41 \pm 0.003$ & $3.15 \pm 0.058$ & $2.75 \pm 0.060$ & $2.47 \pm 0.058$ & $3.20^{\mathrm{a}} \pm 0.044$ & & & \\
\hline & Mean & $3.72^{\mathrm{a}} \pm 0.064$ & $2.83^{b} \pm 0.048$ & $2.45^{\mathrm{c}} \pm 0.049$ & $2.09^{\mathrm{d}} \pm 0.049$ & & & & \\
\hline
\end{tabular}

Means in each row having different superscripts vary significantly at values $\mathrm{p}<0.05$. Again, mean values having same superscript in each row did not differ significantly at $\mathrm{p}>0.05 . \mathrm{T}_{1}=$ Controlled group, $\mathrm{T}_{2}=1.5 \mathrm{kGy}$ irradiated group, $\mathrm{T}_{3}=2 \mathrm{kGy}$ irradiated group, $\mathrm{T}_{4}=4 \mathrm{kGy}$ irradiated group, DI=Days of Interval, $\mathrm{T}=$ Treatment, $\mathrm{T} \times \mathrm{DI}=$ Interaction of Treatment and Days of Interval.

\section{Free Fatty Acid Value (FFA \%)}

The range of overall observed FFA of different treatments was 0.74 to $1.08 \%$. The FFA results appeared to be consistent with those of thiobarbituric acid reactive substances (TBA) and peroxide value (POV). The FFA values are significantly increased with increased irradiation dose and storage time $(\mathrm{P}<0.05)$. Rima et al. (2019) stated that irradiated chicken with $4.5 \mathrm{kGy}$ dose level showed a higher FFA content compared to nonirradiated control samples. Similarly, Chen et al. (2007) found that percentage of saturated fatty acids increased significantly with storage time and after the irradiation.

\section{Microbiological Assessment}

In this study, the effect of gamma irradiation on microflora (TVC) and food borne pathogens (Coliform and Yeast-Mold) on both controlled and irradiated mutton were observed. The results are presented in Table 4.

\section{Total viable count (TVC)}

The range observed of TVC with different treatments value was 5.96 to 3.82 (log CFU/gm). The TVC value was decreased significantly with irradiation dose $(\mathrm{P}<0.05)$. The range of TVC value was 4.72 to 5.17 with different days of intervals. The TVC value was significantly increased with storage time $(\mathrm{P}<0.05)$. Ferawati et al. (2015) reported a lower total plate count in the irradiated samples compared to control. Therefore, it could be said that irradiation is a way of reducing microbial load that might be helpful to increase shelf life of fresh mutton.

Total coliform count (TCC)

Results showed that TCC value was decreased significantly with irradiation dose $(\mathrm{P}<0.05)$. The range of observed TCC with different treatments was 2.51 to 1.29 (log CFU/gm). The TCC values were significantly increased with storage time $(\mathrm{P}<0.05)$. Inamura et al. (2012) reported that irradiated samples showed decrease in TCC and might be safe up to 8 months of storage after gamma irradiation. 
Total yeast-molds count (TYMC)

The TYMC value was decreased significantly with treatment $(3.27$ to $2.09 \log \mathrm{CFU} / \mathrm{gm})(\mathrm{p}<0.05)$, but significantly increased with storage time (2.43 to $3.20 \mathrm{log}$ $\mathrm{CFU} / \mathrm{gm})(\mathrm{p}<0.05)$. The lower value of TYMC indicates that this product is suitable for consumer's health. Similarly, Haque et al. (2017) showed that irradiation significantly decreased yeast and mold count of beef ( $\mathrm{p}<0.05$ ). Ahmed et al. (2009) stated that $4 \mathrm{kGy}$ irradiation levels were suitable for controlling fungal growth on sun dried fish. Badr (2004) reported that the yeasts and molds significantly reduced ( 84 and $94 \%$, respectively) by the irradiation of rabbit meat. Haque et al. (2017) stated that 6 $\mathrm{kGy}$ irradiation dose showed the most acceptable for microbial population reduction, maintains overall acceptability and longer shelf life during beef preservation compared with 2 and $4 \mathrm{kGy}$ irradiation dosages.

\section{Conclusions}

The results of the present study clearly demonstrated that gamma irradiation increased color, tenderness, juiciness and overall acceptability of mutton. Different doses of irradiation increased the shelf life of meat without changing nutritional and sensory properties of meat. Among the treatments, $4.0 \mathrm{kGy}$ showed the best results in terms of sensory attributes, redox control, and microbial population reduction. The main objective of irradiation of meat is to increase the shelflife and to remove the international trade barrier where disease is factors. More study should be needed on specific microorganisms related to spoilage and safety of meats.

\section{Acknowledgements}

The authors are highly grateful to the Bangladesh Agricultural University Research System (BAURES) for funding this research works.

\section{Author Contributions}

Conceptualization: Hashem MA.

Data curation: Islam MA, Hashem MA.

Formal analysis: Islam MA, Hashem MA.

Methodology: Islam MA, Hashem MA.

Validation: Hashem MA.

Investigation: Islam MA, Hashem MA.

Writing -original draft: Islam MA.

Writing, review \& editing: Hossain MA, Sadakuzzaman M, Khan M, Rahman MM.

\section{Ethics Approval}

This article does not require IRB/IACUC approval because there are no human and animal participants

\section{References}

Aftab M, Rafaqat I, Saleem F, Aftab B, Abdullah R, Iqtedar M, Kaleem A, Iftikhar T, Naz S. 2015. Enhancement of shelf life and wholesomeness of goat meat by gamma irradiation treatment. International Journal of Bioscience, 7: 177-185.
Ahmed MK, Hasan M, Alam MJ, Ahsan N, Islam MM, Akter MS. 2009. Effect of gamma radiation in combination with low temperature refrigeration on the chemical, microbiological and organoleptic changes in pampas Chinensis. World Journal of Zoology, 4: 9-13.

Akter H, Akhter S, Rahman SME, Rahman MM, Hossain MM, Ra CS, Kim JM, Oh DH. 2009. Effect of different preservation methods on physicochemical qualities of beef. Journal of Food Hygiene and Safety, 24: 217-225.

Akhter S, Rahman MM, Hossain MM, Hashem MA. 2009. Effects of drying as a preservation technique on nutrient contents of beef. Journal of Bangladesh Agricultural University, 7: 63-68.

Al-Bachir M, Zeinou R. 2009. Effect of gamma irradiation on microbial load and quality characteristics of minced camel meat. Meat Science, 82: 119-124.

AMSA. 1995. American Meat Science Association. Research guidelines for cookery, sensory evaluation, and instrumental tenderness measurements of fresh meat. Chicago III. American Meat Science Association and Nutritional Livestock and Meat Board, USA.

AOAC. 2005. Official methods of analysis (1 $8^{\text {th }}$ edition). Association of Official Analytical, Chemists International, Maryland, USA.

Arannilewa ST, Salawa SO, Sorungbe AA, Olasalawu BB. 2005. Effect of frozen period on the chemical, microbiological and sensory quality of frozen tilapia fish (Sarotherodon galilaleus). African Journal of Biotechnology, 4: 852-855.

Badr HM. 2004. Use of irradiation to control foodborne pathogens and extend the refrigerated market life of rabbit meat. Meat Science, 67: 541-548.

Bakalivanova T, Grigorova S, Kaloyanov N. 2009. Effect of irradiation and packaging on lipid fraction of Bulgarian salami during storage. Radiation Physics and Chemistry, 78: 273-276.

Bithi MAA, Hossain MA, Rahman SME, Rahman MM, Hashem MA. 2020. Sensory, nutritive, antioxidant and antimicrobial activity of Telakucha (Coccnia cordifolia) leaves extract in broiler meatball. Journal of Meat Science and Technology, 8: 23-31.

Bruneau DM, Sebastian P, Lecompte JY, Collignan A, Rochery V. 2005. Sizing of an Innovative and Improved Meat smoking system. International Journal of Food Engineering, 1: 1-18.

Chen YJ, Zhou GH, Zhu XD, Xu XL, Tang XY, Gao F. 2007. Effect of low dose gamma irradiation on beef quality and fatty acid composition of beef intramuscular lipid. Meat Science, 75: 423-431.

Cheung DT, Perelman N, Tong D, Nimni ME. 1990. The effect of $\gamma$-irradiation on collagen molecules, isolated $\alpha$-chains, and crosslinked native fibers. Journal of Biomedical and Material Research, 24: 581-589. https://doi.org/10.1002/jbm.820240505

Choi JH, Kim I, Jueong JY, Lee ES, Choi YS, Kim CJ. 2009. Effects of carcass processing method and curing condition on quality characteristics of ground chicken breasts. Korean Journal of Food Science, 29: 356-363.

DLS. 2018. Department of Livestock Services. Livestock Economy, Dhaka, Bangladesh.

Ferawati, Endang P, Arief, Khalil. 2015. Effect of gamma irradiation technology on the microbial quality and sensory attributes of fresh meat in Pondok Labu traditional market, South Jakarta. Pakistan Journal of Nutrition, 14: 693-697.

Fernandez-Lopez JE, Sayas-Barberá C, Navarro E, Sendra JA. 2003. Physical, chemical, and sensory properties of bologna sausage made with ostrich meat. Journal of Food Science, 68: $1511-1515$.

FSIS, USDA. 2008. Food Safety and Inspection Service, United States Department of Agriculture. The USA. 
Gecgel U. 2013. Changes in some physicochemical properties and fatty acid composition of irradiated meatballs during storage. Journal of Food Science, 50: 505-513.

Ham YK, Kim HY, Huang KE, Song DH, Kim YJ, Choi YS, Song BS, Park JH, Kim CJ. 2017. Irradiation source and dose level on quality characteristics of processed meat products. Radiation Physics and Chemistry, 130: 259-264.

Haque MA, Hashem MA, Hossain MM, Rima FJ, Hossain AA. 2017. Effect of gamma irradiation on shelf life and quality of beef. Journal of Meat Science and Technology, 5: 20-28.

Hashim LB, Resurreccion AVA, Mc Watters KH. 1995. Descriptive sensory analysis of Irradiated frozen refrigerated chicken. Journal of Food Science, 60: 664-666.

Inamura PY, Uehara VB, Teixeira Christian AHM, Mastro NL. 2012. Mediate gamma radiation effects on some packaged food items. Radiation Physics and Chemistry, 81: 1144-1146.

Inguglia ES, ES, Zhang Z, Burgess C, Kerry JP, Tiwari BK. 2018. Influence of extrinsic operational parameters on salt diffusion during ultrasound assisted meat curing. Ultrasonics. 83: 164170.

Islam A, M Sadakuzzaman, MA Hossain, MM Hossain, MA Hashem, 2019. Effect of gamma irradiation on shelf life and quality of indigenous chicken meat. Journal of Bangladesh Agricultural University, 17: 560-566.

ISO. 1995. Recommendation of the meeting of the subcommittee, International Organization for Standardization, on meat and meat products. ISO/TC- 36/SC-6. The Netherlands. 10-18.

Johnson A, Estes RA, Jinru C, Resureccion AVA. 2004. Consumer attitudes toward irradiated food: 2003 vs. 1993. Food Protection Trends, 24: 408-418.

Jung HH. 2007. Packaging for foods treated with ionizing radiation. Blackwell Publishing.

Kanatt KSR, Chander R, Sharma A. 2006. Effect of radiation processing of lamb meat on its lipids. Food Chemistry, 97: 80-86.

Kim IS, Jo C, Lee KH, Lee EJ, Ahn DU, Kang SN. 2012. Effects of low-level gamma irradiation on the characteristics of fermented pork sausage during storage. Radiation Physics and Chemistry, 81: 466-472.

Kim IS, Jin SK, Kang SN, Hur IC, Choi SY. 2009. Effect of oliveoil prepared tomato powder (OPTP) and refining lycopene on the physicochemical and sensory characteristics of seasoned raw pork during storage. Korean Journal of Food Science, 29: 329-334.

Konieczny P, Stangierski J, Kijowski J. 2007. Physicaland chemical characteristics and acceptability of home style beef jerky. Meat Science, 76: 253-257.

Miller SJ, Moss BW, MacDougall DB, Stevenson MH. 1995. The effect of ionizing radiation on the CIELAB color co-ordinates of chicken breast meat as measured by different instruments. International Journal of Food Science and Technology, 30: 663-674.

Miyagusku L, Miyagusku F, Chen MF, De F, Leitão O. 2003. Baffa Avaliação microbiológica e sensorial da vidaútil de cortes de peito de fangosirradiados. Ciência e Tecnologia de Alimentos, 23: 07-16.

Modak AK, Akter S, Hashem MA, Hossain MM. 2009. Effect of freezing temperature and defrosting methods on the quality of beef. Journal of Bangladesh Society for Agricultural Science and Technology, 6: 29-32.

Modi VK, Sakhare PZ, Sachindra NM, Mahendrakar NS. 2008. Changes in quality of minced meat from goat due to gamma irradiation. Journal of Muscle foods, 19: 430-442.
Morales DA, Moreno-Indias I, Falcon A, Arguello A, SanchezMacias D, Capote J, Castro N. 2009. Effects of various packaging systems on the quality characteristic of goat meat. Asian-Australasian Journal of Animal Sciences, 22: 428-432.

Nam KC, Min BR, Park KS, Lee SC, Ahn DU. 2003. Effects of ascorbic acid and antioxidants on the lipid oxidation and volatiles of irradiated ground beef. Journal of Food Science, 68: $1680-1685$.

Quattara B, Giroux G, Myefsah R, Smoragiewicz W, Saucie, L, Borsa J. 2002. Microbiological and biochemical characteristics of ground beef as affected by gamma irradiation, food additives and edible coating film. Radiation Physics and Chemistry, 63: 299-304.

Rahman MH, Hossain MM, Rahman SME, Hashem MA, Oh DH. 2014. Effect of repeated freeze-thaw cycles on beef quality and safety. Korean Journal for food Science of Animal Resources, 34: 482-495.

Rahman SM, Park J, Song KB, Al-Harbi NA, Oh DH. 2012. Effect of slightly acidic low concentration electrolyzed water on microbiological, physicochemical, and sensory quality of fresh chicken breast meat. Journal of Food Science, 77: 3541.

Rima FJ, M Sadakuzzaman, MA Hossain, MS Ali and MA Hashem, 2019. Effect of gamma irradiation on shelf life and quality of broiler meat. SAARC Journal of Agriculture, 17: 149-159.

Roberts PB. 2014. Food irradiation is safe: Half a century of studies. Radiation Physics and Chemistry, 105: 78-82.

Rukunudin IH, White PJ, Bern CJ, Bailey TB. 1998. Amodified method for determining free fatty acids from small soybean sample sizes. Journal of American Oil Chemistry Society, 75: 563-568.

Sallam KI, Ishioroshi M, Samejima K. 2004. Antioxidants and antimicrobial effects of garlic in chicken sausage. Lebensmittel-Wissenschaft Technology, 37: 849-855.

Schmedes A, Homer G. 1989. A new thiobarbituricacid (TBA) method for determining freemalondialdehyde (MDA) and hydroperoxides selectively as a measure of lipid peroxidation. Journal of American Oil Chemistry Society, 66: 813-817.

Shin MH, Lee JW, YoonYM, Kim JH, Moon BG, Song BS. 2014. Comparison of quality of bologna sausage manufactured by electron beam or X-rayirradiated ground pork. Korean Journal of Food Science, 34: 464-471.

Stefanova R, Toshkov SN, Vasilev V, Vassilev NG, Marekov IN. 2011. Effect of gamma-ray irradiation on the fatty acid profile of irradiated beef meat. Food Chemistry, 127: 461-466.

Sweetie R, Kanattn, Chawla SP, Arun, Sharma. 2015. Effect of radiation processing on meat tenderization. Radiation Physics and Chemistry, 111: 1-8.

Thayer DW, Boyd G, Fox JB, Lakritz L, Hampson JW. 1995. Variations in radiation sensitivity of food borne pathogens associated with the suspending meat. Journal of Food Science, 60: 63-67.

WHO, 1999. World Health Organization. Safety and Nutritional Adequacy of Irradiated Food. Geneva.

Yilmaz I, Gecgel U. 2007. Effects of gamma irradiation on trans fatty acid composition in ground beef. Food Control, 18: 635638.

Yoon KS. 2003. Effect of gamma Irradiation on the texture and microstructure of chicken breast meat. Meat Science, 63: 273277.

Zhu M, Du M, Cordray J, Ahn DU. 2005. Control of Listeria monocytogenesis contamination in ready-to-eat meat products. Comprehensive Reviews in Food Science and Food Safety, 4: 34-42. 